\title{
OPTIMALISASI PENGGUNAAN ATRIBUT USAHA UNTUK MENINGKATKAN OMZET TERASI REBON KABUPATEN TUBAN
}

\author{
Mahmudah Enny Widyaningrum ${ }^{1}$, Abdul Fattah $^{2}$, Soehardjoepri ${ }^{3}$, \\ Muslichah Erma widiana ${ }^{4}$, Tri Sagirani ${ }^{5}$ \\ 1,2,4 Universitas Bhayangkara Surabaya \\ ${ }^{3}$ Institut Teknologi Sepuluh Nopember \\ ${ }^{5}$ Universitas Dinamika \\ 12ennymahmudah@yahoo.co.id, ${ }^{2}$ abdulfattah6567@gmail.com, ${ }^{3}$ djoepri.its@gmail.com, \\ ${ }^{4}$ erma@ubhara.ac.id, ${ }^{5}$ tris@dinamika.ac.id
}

\begin{abstract}
Terasi is one of the main fishery products made from rebon shrimp and fish. Regional Superior Product Development Program (PPPUD) in collaboration with UD. HM. Putra Bahari, which is one of the micro, small, and medium enterprises that produce shrimp processed in the form of terasi that is superior in Tuban Regency. Utilization and operational management of store management is still weak, so the optimization of the packaging and marketing process through the use of business attributes becomes important. The program provides alternative solutions for partners. Implementation methods for solving problems include identifying partner readiness, situation analysis, needs analysis and implementation. The program is focused on the preparation of shop and exhibition equipment.
\end{abstract}

Keyword: terasi, shrimp, product development program

\section{PENDAHULUAN}

Menurut data yang disampaikan oleh Badan Pusat Statistik Kabupaten Tuban disebutkan bahwa Kabupaten Tuban merupakan salah satu kabupaten yang terletak di Propinsi Jawa Timur (111030' - 112035' BT dan 6040'- 7018' LS). Batas Daerah, disebelah utara berbatasan dengan Laut Jawa, sebelah timur dengan Kabupaten Lamongan, sebelah selatan dengan Kabupaten Bojonegoro dan disebelah barat dengan Propinsi Jawa Tengah. Luas Wilayah Daratan, Kabupaten Tuban adalah 1.839,94 Km2 dengan panjang pantai $65 \mathrm{Km}$ dan luas wilayah lautan sebesar $22.608 \mathrm{Km}^{2}$ (Badan Pusat Statistik Kabupaten Tuban, 2020). Kondisi geografis ini membuat produksi perikanan di Kabupaten Tuban cukup melimbah, dari data yang disampaikan dalam publikasi berjudul Kabupaten Tuban dalam Angka bahwa jumlah produksi perikanan tangkap di Kabupaten Tuban pada tahun 2019 mencapai 20.645,30 ton, dengan rincian hasil perikanan laut sebesar 18.148,80 ton dan perairan umum sebesar 2.496,70 ton. Jumlah tersebut memberikan kontribusi yang cukup tinggi untuk wilayah profinsi Jawa Timur. Keberlanjutan dari hasil perikanan ini terletak pada proses pengolahan menjadi produk yang memiliki nilai ekonomis, salah satunya adalah produk terasi.

Terasi merupakan salah satu produk perikanan berbahan dasar utama udang rebon dan juga ikan yang dalam proses pembuatannya dilakukan melalui fermentasi (Farhan Alfarobi Karim, 2014). Fermentasi merupakan proses penguraian daging yang dilakukan oleh enzim yang memberikan hasil dan menguntungkan (Murniyati, 2020). Proses fermentasi serupa dengan pembusukan, tetapi fermentasi menghasilkan zat-zat yang memberikan rasa dan aroma yang spesifik dan disukai orang. Rasa dan aroma yang spesifik ini dapat dirasakan pada ikan peda, terasi, kecap ikan, petis dan sebagainya. Bentuk dari terasi pada umumnya adalah padat, teksturnya agak kasar, dan memiliki aroma yang khas dan tajam namun rasanya sangat gurih (Subagio, 2006). Rasa gurih yang dihasilkan terasi bersumber dari senyawa asam amino (asam glutamat dan asam nukleat). Kabupaten Tuban merupakan salah satu penghasil terasi yang cukup terkenal.

Dalam pengembangan produk pengolahan hasil perikanan berupa terasi, maka penulis melaksanakan Program Pengembangan Produk Unggulan Daerah (PPPUD) yang bekerjasama dengan UD. HM. Putra Bahari sebagai mitra. UD. HM. Putra Bahari yang 
merupakan salah satu UMKM yang menghasilkan produk olahan udang yaitu terasi rebon yang menjadi unggulan di Kabupaten Tuban. UD. HM. Putra Bahari beralamat di Karang Agung Barat RT/RW 01/01 Ds. Karang Agung Kec. Palang Tuban, Jawa-Timur. Kecamatan Palang Kabupaten Tuban merupakan satu dari lima kecamatan di Kabupaten Tuban yang menghasilkan produksi perikanan laut. Dalam buku Kabupaten Tuban dalam Angka yang disampaikan oleh Badan Pusat Statistik Kabupaten Tuban, tercatat pada tahun 2019 Kecamatan Palang menghasilkan 9.736,17 ton perikanan laut, hasil tertinggi di Kabupaten Tuban yang memberi kontribusi sebesar 53,65\% dari keseluruhan hasil produksi perikanan laut.

Analisa terhadap usaha mitra telah dilakukan selanjutnya dapat dirumuskan strategi peningkatan hasil (Ismail Solihin, 2012) dan juga strategi pemasaran (Fandy Tjiptono, 2008) yang memungkinkan untuk dilaksanakan. Analisa ini mendapatkan hasil bahwa mitra memiliki beberapa kekuatan yaitu mitra mampu menghasilkan bahan penyedap untuk aneka olahan masakan yang mempunyai rasa yang khas, unik, bahan ini mudah didapat, bergisi dan memiliki harga ekonomis dan sangat digemari. Namun demikian mitra juga memiliki kelemahan yaitu lemah pada pemasaran produk, sering terjadi kesalahan dalam pengolahan, pemasaran kurang maksimal dan kurangnya inovasi dalam proses pengolahan. Sehingga diperlukan suatu inovasi dan pemasaran online (Baidawi, M., Rahayu, Y. N., \& Harmadji, D. E, 2017, 2018)

Kendala utama yang muncul dalam pengelolaan UD. HM. Putra Bahari adalah pemanfaatan dan pengaturan operasional manajemen toko yang masih lemah, pengaturan ruang untuk toko, desain toko, ruang pamer, meliputi etalase, meja kasir, kursi pengunjung, dan optimalisasi proses pengemasan dan pemasaran. Metode pelaksanaan yang digunakan untuk menyelesaikan permasalahan yang dihadapi mitra meliputi tahapan identifikasi kesiapan mitra, analisa situasi, analisa kebutuhan, dan implementasi. Pada pelaksanaan pengabdian masyarakat ini difokuskan pada persiapan pembuatan toko dan perangkat pameran. Dengan berkembangnya tempat layanan berupa toko yang nyaman bagi pelanggan dan juga pegawai diharapkan mampu menarik pelanggan baru dan mempertahankan pelanggan lama untuk tetap menggunakan produk hasil olahan dari mitra, dengan demikian program ini mampu memberikan peningkatan omzet dari UD. HM. Putra Bahari sebesar $45 \%$.

\section{METODE}

Metode pelaksanaan untuk menyelesaikan permasalahan yang dihadapi mitra meliputi identifikasi kesiapan mitra, analisa situasi, analisa kebutuhan, implementasi. Tahapan pada metode pelaksanaan dapat dilihat pada Gambar 1 berikut ini.

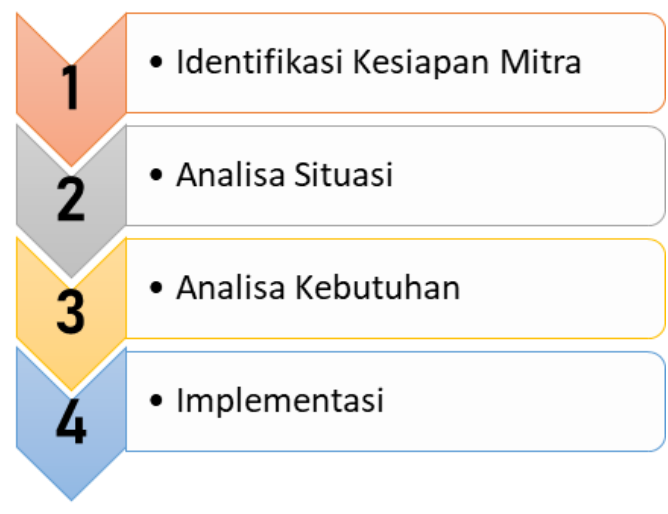

Gambar 1 Metode pelaksanaan program 
Identifikasi Kesiapan Mitra

Aktifitas mencari, menemukan, mengumpulkan, meneliti, mendaftarkan, mencatat data dan informasi dari kesiapan mitra di lapangan untuk mengetahui berbagai masalah atau kebutuhan program yang dibutuhkan oleh mitra.

Analisa Situasi

Tahap pengumpulan data yang ditempuh sebelum merancang dan merencanakan program (Freddy Rangkuti, 2004). Analisa yang dilakukan pelaksana adalah analisa SWOT (Strenght, Weakness, Opportunities, Threats).

Analisa Kebutuhan

Melakukan pekerjaan untuk penentuan kebutuhan atau kondisi yang harus dipenuhi dalam menyelesaikan permasalahan mitra dengan mempertimbangkan berbagai kebutuhan yang bersinggungan antar berbagai pemangku kepentingan.

Implementasi

Melaksanakan program sesuai rencana yang telah disusun pada tahapan identifikasi kesiapan mitra, analisa situasi dan analisa kebutuhan.

\section{HASIL KARYA UTAMA DAN PEMBAHASAN}

Pada bagian ini akan disampaikan hasil karya utama dan pembahasan untuk setiap tahapan yang disampaikan pada metode pelaksanaan yaitu hasil pada tahap identifikasi, tahap analisa situasi, tahap analisa kebutuhan dan yang terakhir implementasi.

\section{Hasil Identifikasi}

Dari pelaksanaan wawancara langsung dengan pemilik usaha dan observasi terhadap usaha baik secara fisik maupun manajemen yang dijalankan, maka diperoleh data seperti pada Tabel 1 berikut ini:

Tabel 1. Data UD. HM Putra Bahari

\begin{tabular}{|c|c|}
\hline Kondisi Mitra & Keterangan \\
\hline Status Usaha & $\begin{array}{l}\text { Perusahaan perseorangan yang berawal dari usaha keluarga, yang } \\
\text { mengawali usaha sejak tahun } 1979 \text { dan saat ini sudah dikelola } \\
\text { oleh generasi kedua }\end{array}$ \\
\hline Merk Usaha & VIA \\
\hline Jenis Usaha & Perdagangan hasil perikanan ( terasi rebon Tuban ) \\
\hline Jenis Produk & $\begin{array}{l}\text { Pengolahan hasil laut terasi rebon. } \\
\text { Terdapat } 2 \text { jenis : } \\
\text { 1. Bentuk kemasan kotak (mentah) } \\
\text { 2. Bentuk kemasan botol (matang) }\end{array}$ \\
\hline $\begin{array}{l}\text { Kualitas } \\
\text { kemasan kotak }\end{array}$ & $\begin{array}{l}\text { 1. Kwalitas 1: terasi bagus terbuat terbuat dari rebon } \\
\text { basah/krakalan kwalitas super } \\
\text { 2. kwalitas 2: campuran udang basah/krakalan dan udang } \\
\text { kering } \\
\text { 3. kwalitas 3: hanya rebon kering }\end{array}$ \\
\hline $\begin{array}{l}\text { Kualitas } \\
\text { kemasan botol }\end{array}$ & $\begin{array}{l}\text { 1. Kemasan warna ungu butiran halus, } \\
\text { 2. Kemasan warna kuning butiran sebesar micin, } \\
\text { 3. Kemasan warna orange butiran sebesar merica. } \\
\text { 4. Kemasan warna hijau kwalitas } 2 \text {. }\end{array}$ \\
\hline $\begin{array}{l}\text { Kapasitas } \\
\text { Produksi }\end{array}$ & $\begin{array}{l}12.000 \mathrm{~kg} / \mathrm{th} \\
\text { Kapasitas dipengaruhi tingkat pemanasan sinar matahari. }\end{array}$ \\
\hline $\begin{array}{l}\text { Fasilitas } \\
\text { ruangan }\end{array}$ & $\begin{array}{l}\text { Ruangan yang digunakan : } \\
\text { - Ruang bahan baku } 10 \mathrm{~m} \times 10 \mathrm{~m} \\
\text { - Ruang cetak } 8 \mathrm{~m} \times 10 \mathrm{~m}\end{array}$ \\
\hline
\end{tabular}




\begin{tabular}{ll}
\hline & - Ruang packing dan stok $8 \mathrm{~m} \times 20 \mathrm{~m}$ \\
& - Ruang giling $7 \mathrm{~m} \times 10 \mathrm{~m}$ \\
& - Ruang jemur $8 \mathrm{~m} \times 10 \mathrm{~m}$ \\
\hline Fasilitas & Fasilitas yang digunakan dalam produksi \\
Peralatan & - Mesin giling \\
& - Alat pengaduk kayu \\
& - Alat cetak kayu \\
& - Kotak untuk jemur terasi \\
& - Kendaraan \\
\hline Konsumen & Pulau Jawa dan sekitarnya \\
\hline Bahan baku & Udang basah dan Udang kering \\
\hline Produksi & Terasi rebon \\
\hline Konsumen & Rumah tangga dan Bisnis \\
\hline Pasar & Rumah tangga, pasar tradisional, lokal, pasar swalayan, pusat \\
& oleh-oleh dan rumah makan. \\
\hline Proses & Manual dan semi otomatis. Proses penjemuran dilakukan dengan \\
& memanfaatkan panas matahari \\
\hline Produk & Kemasan kertas dan botol plastik sudah berizin \\
\hline Manajemen & Fungsi operasional manajemen belum berjalan. \\
\hline SDM & Memiliki 8 karyawan tetap, dan 20 karyawan tidak tetap \\
\hline Finansial & Modal pribadi \\
\hline Pengembangan & Perlu ada inovasi dan pendampingan \\
\hline
\end{tabular}

\section{Hasil Analisa Situasi dan Analisa Kebutuhan}

Tahapan berikutnya adalah menyampaikan hasil dari analisa situasi dari usaha mitra. Analisis situasi disampaikan dalam matrik SWOT berkaitan dengan usaha olahan hasil laut dari pesisir yaitu terasi Tuban disampaikan pada Tabel 2 berikut :

\section{Tabel 2. Hasil Analisis SWOT}

\begin{tabular}{|c|c|c|}
\hline No. & Analisis & Hasil Analisis \\
\hline 1. & $\begin{array}{l}\text { Strenght/ } \\
\text { kekuatan }\end{array}$ & $\begin{array}{l}\text { 1. Sebagai bahan aneka olahan masakan, mempunyai rasa yang } \\
\text { khas, unik. } \\
\text { 2. Bahan baku sangat mudah didapatkan karena berada di } \\
\text { lingkungan laut daerah pesisir. } \\
\text { 3. Bergizi. } \\
\text { 4. Harga ekonomis } \\
\text { 5. Banyak konsumen dan pasar yang membutuhkan. } \\
\text { 6. Belum banyak yang memproduksi produk terasi rebon. } \\
\text { 7. Produk yang selalu dicari penambah cita rasa masakan. } \\
\text { 8. Merupakan produk yang khas dari Tuban }\end{array}$ \\
\hline 2. & $\begin{array}{l}\text { Weakness/ } \\
\text { Kelemahan }\end{array}$ & $\begin{array}{l}\text { 1. Pemasaran produk masih kurang sehingga produk ini masih } \\
\text { belum dikenal secara luas. } \\
\text { 2. Sering terjadi kesalahan dalam pengolahan/ berproduksi } \\
\text { 3. Lokasi produksi masih terlalu jauh dengan lingkungan } \\
\text { warga, sehingga produksi dan pemasaran kurang maksimal. } \\
\text { 4. Kurang inovasi dalam pengolahannnya. }\end{array}$ \\
\hline 3. & $\begin{array}{l}\text { Opportunities/ } \\
\text { Peluang }\end{array}$ & $\begin{array}{l}\text { 1. Tidak semua daerah/kota dapat memproduksi terasi. } \\
\text { 2. Produk terasi rebon yang lain masih jarang sekali } \\
\text { promosinya, sehingga menjadi kesempatan besar untuk terus } \\
\text { mengembangkan usaha ini. } \\
\text { 3. Bahan baku udang rebon yang berlimpah, sehingga sangat } \\
\text { baik untuk dimanfaatkan. }\end{array}$ \\
\hline
\end{tabular}


PEDULI: Jurnal Ilmiah Pengabdian Pada Masyarakat, 2020, Vol.4, No.1

ISSN: 25974653. EISSN:25974688

http://peduli.wisnuwardhana.ac.id/index.php/peduli/index

4. Berbagai makanan olahan di Indonesia bahkan mancanegara membutuhkan terasi sebagai bahan dasar masakan sehingga memiliki rasa yang khas dan unik.

4.

Threats/

Ancaman
1. Informasi konsumen dan pasar tentang adanya terasi rebon yang merupakan produk unggulan di Tuban belum semuanya mengetahui.

2. Kurangnya varian rasa dan pengemasan menjadikan pilihan konsumen sedikit.

3. Konsumen awam dalam memilih terasi lebih pada pilihan yang mudah ditemui.

\section{Hasil Implementasi}

Dari identifikasi dan Analisa situasi, diperoleh masalah yang ada pada mitra yaitu masih lemahnya manajemen usaha, pengaturan ruang untuk toko, desain toko, ruang pamer, meliputi etalase, meja kasir, kursi pengunjung, dan optimalisasi proses pengemasan. Pada pelaksanaan pengabdian masyarakat kali ini difokuskan pada persiapan pembuatan toko dan perangkat pameran. Gambar 2 adalah aktifitas pengaturan ruangan yang dipergunakan untuk took meliputi pengaturan barang siap jual, bahan baku, rak beserta etalase.

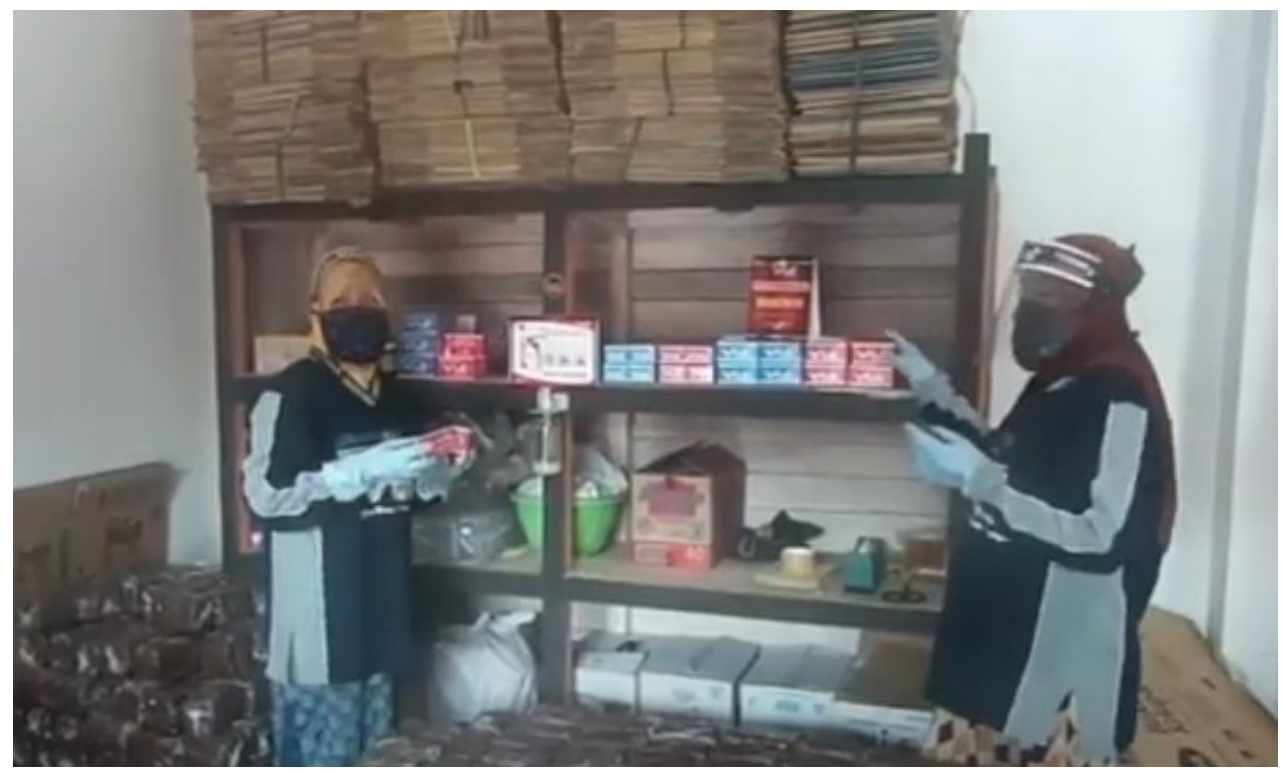

Gambar 2 Pengaturan Ruang Toko

Hal yang penting dan dibutuhkan mitra diantaranya adalah mempersiapkan kebutuhan perlengkapan pameran yang terdiri rancangan ruang pamer, etalase, meja kasir, kursi pengunjung dan seragam karyawan. Gambar 3 berikut ini adalah desain ruang pamer yang digunakan oleh mitra Ketika mengikuti gelar produk unggulan daerah yang biasa diselenggarakan di dalam kota maupun di luar kota Tuban. 


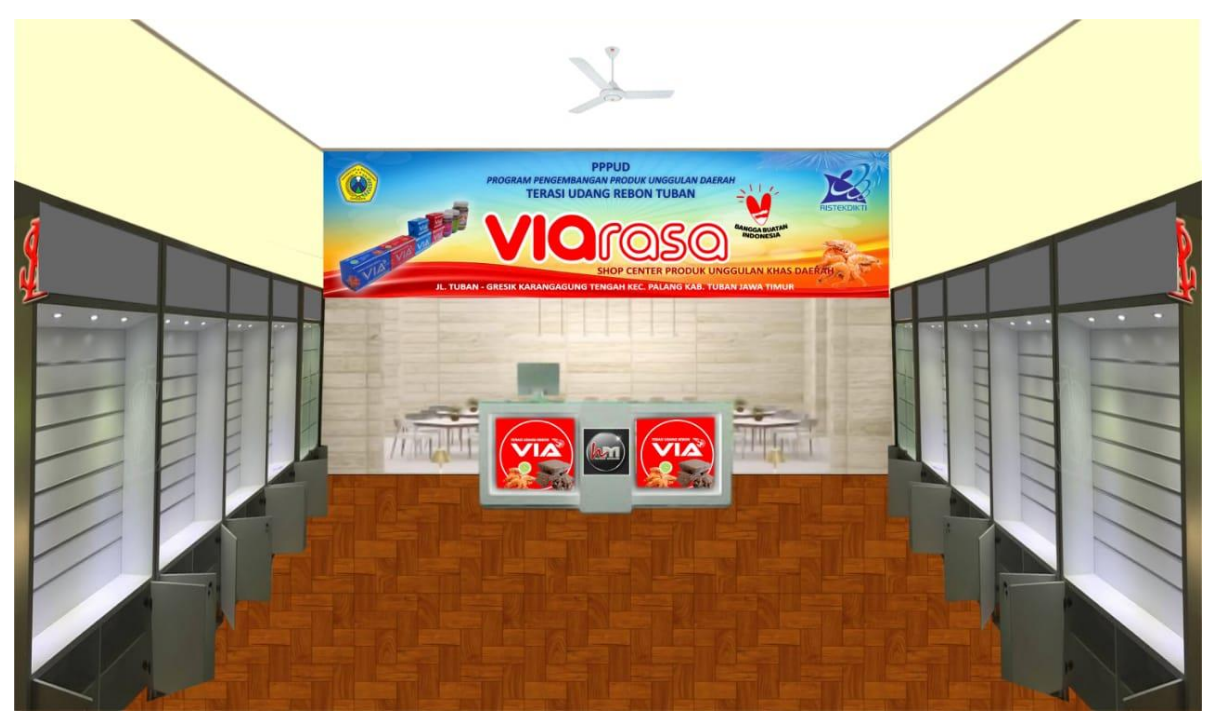

Gambar 3 Desain ruang pamer

Guna membangun rasa memiliki dan loyalitas dari karyawan maka keberadaan/ penggunaan atribut usaha mitra sangat dibutuhkan, salah satunya dengan seragam yang digunakan untuk mendukung kegiatan pameran. Gambar 4 berikut ini adalah desain seragam yang disiapkan, tampak bagian depan berikut pembesaran dari desain logo dan juga bagian belakang seragam.

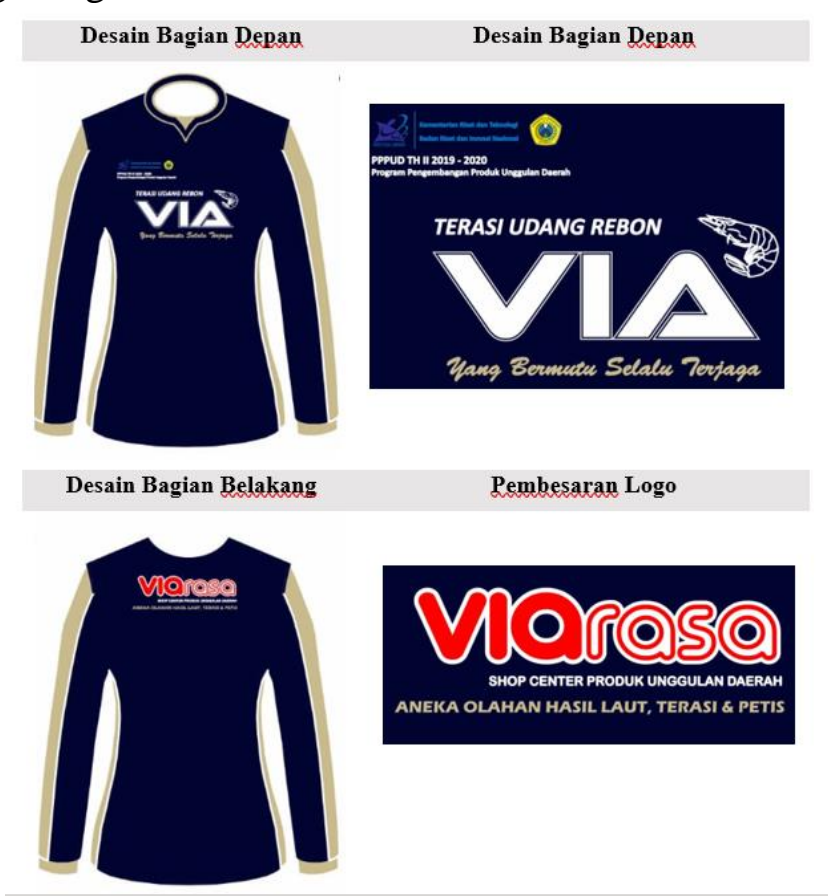

Gambar 4 Desain seragam

Pemilihan warna, model seragam dan tribut yang dituliskan dalam logo dan teks pada seragam adalah hasil rekomendasi pelaksana yang telah disetujui oleh mitra dan terdiri dari :

- Logo dan teks Kementerian Riset Teknologi/ Badan Riset dan Inovasi Nasional

- Logo dan teks Perguruan Tinggi

- Nama program, nama produk, merek produk dan tagline produk 
Dalam pemanfaatannya, seragam ini mampu membuat semangat kerja pegawai meningkat. Kenyamanan dari bahan dan bentuk jahitan tidak menghalangi ruang gerak dari pegawai saat menjalankan aktifitas produksi dan juga melayani pelanggan. Gambar 5 berikut ini adalah aktifitas pegawai dalam kegiatan produksi.

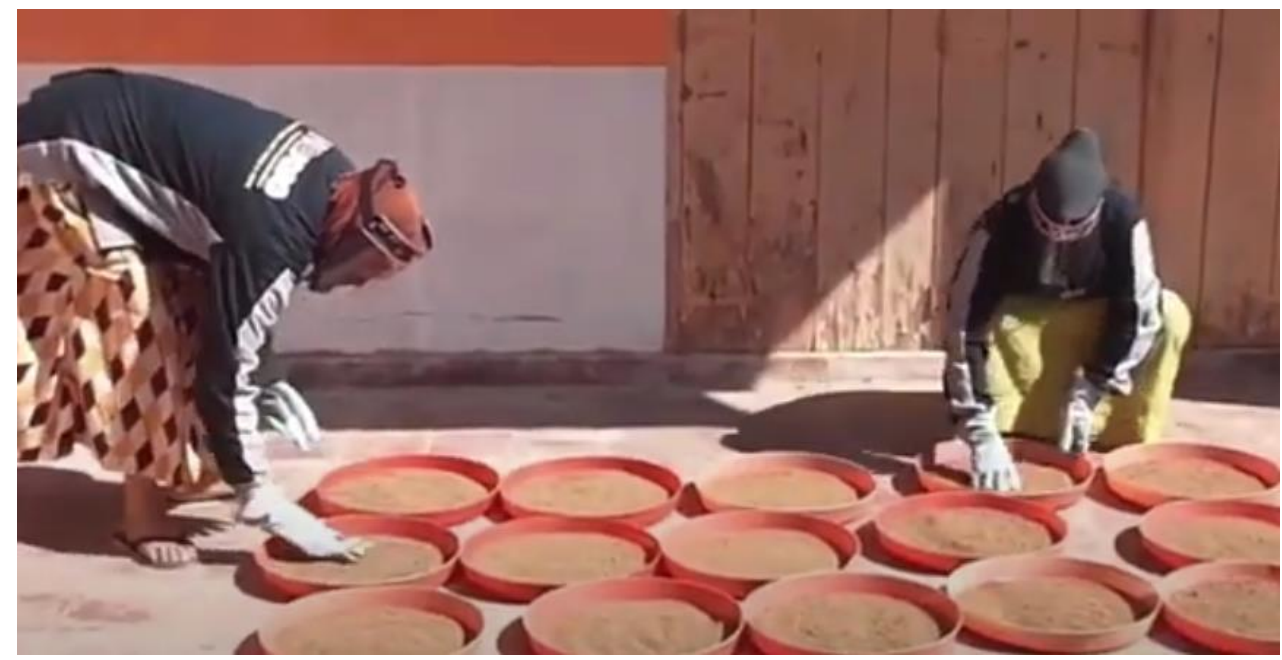

Gambar 5 Aktifitas produksi

Dari keseluruhan aktifitas yang telah dilaksanakan dengan berfokus pada mempersiapkan ruang produksi, toko dan ruang pamer maka dapat diukur keberhasilan program capaian yang telah dihasilkan oleh mitra, antara lain adalah :

- Peningkatan omzet bulanan mitra sebesar $45 \%$

- Peningkatan loyalitas pegawai yang ditunjukkan dengan komunikasi yang semakin baik antara pemilik dan pegawai dan antar pegawai itu sendiri.

- Peningkatan loyalitas ini juga ditunjukkan dengan tingginya tingkat kehadiran pegawai.

Program ini terus berjalan dan berkelanjutan, melalui pendampingan, monitoring dan sekaligus evaluasi hasil setelah berjalan dua tahun bermitra, diharapkan dengan pendampingan ini mitra dapat mempertahankan hasil yang telah didapat bahkan dapat meningkatkan penghasilannya.

\section{KESIMPULAN}

Program Pengembangan Produk Unggulan Daerah ini bermitra dengan UD. HM Putra Bahari berhasil dilaksanakan di Kota Tuban dan dapat meningkatkan omzet yang dimiliki oleh mitra. Program ini menghasilkan perbaikan pada pengelolaan usaha khususnya pada aktifitas manajemen toko dan mempersiapkan kelengkapan untuk pameran. Penggunaan atribut seragam pegawai turut memberikan dampak pada kenyamanan pegawai dalam bekerja, inipun mempengaruhi semangat kerja dan keaktifan pegawai yang secara tidak langsung mampu meningkatkan jumlah kehadiran pegawai.

\section{UCAPAN TERIMA KASIH}

Pelaksanaan Program Pengembangan Produk Unggulan Daerah didukung penuh oleh Direktorat Riset dan Pengabdian Masyarakat, Deputi Bidang Penguatan Riset dan Pengembangan, Kementerian Riset Teknologi/ Badan Riset dan Inovasi Nasional, sesuai Kontrak Pelaksanaan Program Pengabdian Kepada Masyarakat Nomor: 105/SP2H/PPM/DRPM/2020, tanggal 16 Maret 2020 


\section{DAFTAR PUSTAKA}

Badan Pusat Statistik Kabupaten Tuban. 2020. Kabupaten Tuban Dalam Angka. Tuban: BPS Kabupaten Tuban.

Baidawi, M., Rahayu, Y. N., \& Harmadji, D. E. (2017). Pengembangan Produk Ekspor Batik Podhek di Kabupaten Pamekasan Provinsi Jawa Timur. JPM (Jurnal Pemberdayaan Masyarakat), 2(2), 130-138.

Baidawi, M., Rahayu, Y. N., \& Harmadji10, D. E. PPPUD INDUSTRI BATIK PODHEK DI KABUPATEN PAMEKASAN PROVINSI JAWA TIMUR.

Fandy Tjiptono. (2008). Strategi Pemasaran. Sleman, Penerbit ANDI.

Farhan Alfarobi Karim, F. S. 2014. Pengaruh Perbedaan Bahan Baku Terhadap Kandungan Asam Glutamat Pada Terasi. Jurnal Pengolahan dan Bioteknologi Hasil Perikanan Jurnal Pengolahan dan Bioteknologi Hasil Perikanan.

Freddy Rangkuti. 2004. Analisis SWOT Teknik Membedah Kasus Bisnis: Reorientasi Konsep Perencanaan Strategi untuk Menghadapi Abad 21. Jakarta, Gramedia Pustaka Utama

Ismail Solihin. 2012. Manajemen Strategik. Bandung, Penerbit Erlangga

Murniyati, A. d. 2020. Pendinginan pembekuan dan pengawetan ikan. Yogyakarta: Kanisius.

Subagio. 2006. Mengembangkan Terasi Instan. Food Review Indonesia Vol. 1 No.9 Oktober 2006. 